\title{
Assessment of national policy to promote corporate governance in Nepal
}

\author{
Authors \\ Heena Tandukar: \\ Envision working \\ as a manager in \\ banking and financial \\ sector to develop a \\ professional career. \\ aneehtandukar21@ \\ gmail.com \\ Anar Niroula: \\ Aims to serve as an \\ effective institutional \\ performance \\ transformation manager \\ in BFIs by means of \\ personal branding. \\ Kirit Shrestha: Displays \\ keen interest to portray \\ an enhanced form of \\ consulting service to \\ safeguard organizations \\ from impeding \\ problems, issues and \\ challenges. \\ Udaya Raj Paudel: \\ Principal, Quest \\ International College

\section{Key Words} \\ Bank and Financial \\ Institution Act (BAFIA), \\ Basel Committee, \\ corporate governance; \\ Organization for \\ Economic Corporation \\ and Development \\ (OECD) principles
}

\begin{abstract}
Background: Corporate governance, or good governance may have a direct impact not only on economic health of an organization, but also the overall status of national governance or systems administration. By now, Nepal has succeeded to attain political stability and attainment of policy stability is in its making. It is right time for all type of organizations to institute favorable traditions, customs, policies, rules and regulations with increased level of accountability to help the nation with right policy direction. Therefore, reviewing the Nepalese corporate governance scenario by assessing governing policies, prevailing issues, challenges and practices deem necessary.
\end{abstract}

Objectives: The main purpose of this paper was to establish an assessment of national policy effectiveness on corporate governance, specifically in the banking sector.

Methods: Fully based on desk review performed in a qualitative setting of inquiry.

Results: There is closer linkage between legal and regulatory provisions and effectiveness of corporate governance in the Nepalese banking sector.

Conchusions:For an emerging economies, improving the level of corporate governance can serve a number of important public policy objectives such as reducing market vulnerability to financial crises, controlling transaction costs and cost of capital, and resulting with investor confidence and capital market development situation.

Implications: Nepal needs timely review and updates in not only policies governing bank and financial institutions, but also the entire company's act of the country to make all type of organizations accountable and transparent in their operations to win the investor confidence and market trust.

Paper type: Review paper pal. Quest Journal of Management and Social Sciences: Corporate Governance Edition, 1(1), 73-95. Kathmandu: Quest Scientific Publications. 


\section{Introduction}

Corporate governance (CG) has been receiving a lot of attention due to its positive impact on the overall economic as well as professional dimension of the corporation. While financial crisis at culmination, regulators, government and academicians tend to focus on the corporate governance more enthusiastically in order to enhance investors' confidence that would attract more employment of fund in business. Corporate governance is the set of processes, customs, policies, laws and institutions, affecting the way a company is directed, administered or controlled. The Cadbury Committee of UK defined corporate governance as - "the system by which companies are directed and controlled" (Cadbury Committee, 2000; as cited in Aggarwal, 2013). This scholar has observed the relationships among the various stakeholders including internal members, other shareholders, management and board of directors (BODs) involved and the goals for which the corporation is governed.

Corporate governance broadly refers to the mechanisms, processes and relations by which corporations are controlled and directed. Governance structures and principles identify the distribution of rights and responsibilities among different participants in the corporation (such as the board of directors, managers, shareholders, creditors, auditors, regulators, and other stakeholders) and include the rules and procedures for making decisions in corporate affairs. Corporate governance includes the processes through which corporations' objectives are set and pursued in the context of the social, regulatory and market environment. Governance mechanisms include monitoring the actions, policies, practices, and decisions of corporations, their agents, and affected stakeholders. Further, other scholars have suggested that corporate governance is a set of rules, institutions, practices that minimize the agency cost and the divergence between social and private returns on corporate activity (Ararat \& Vyur, 2016). According to ASX Corporate Governance Council (2003), a good corporate governance required ten important principles, they are: lay solid foundations for management oversight, structure a board to add value, promote ethical and responsible decision-making, safeguard integrity in financial reporting, make timely and balanced disclosure, respect the right of shareholders, recognize and manage risks, encourage enhanced performance, remunerate fairly and responsibly and recognize the legitimate interests of stakeholders.

In Nepal, corporate culture is becoming essential part of the business and it is slowly adopting the pace to get its ground. Therefore, it is very important that good practices are inculcated in our corporate culture from the birth itself. In order to attract FDIs and induce large investment in joint stock companies will require effective and productive management structures by laws as well as by practices so as to meet the acceptance of all stake holders. The companies having good corporate governance are uniformly transparent, systematic and with segregation of power between owners and the managers. Investors are delighted and are inclined towards such companies. According to Agrawal (2017) board of directors are the investors' curator of trust and believe that they take the decisions on their behalf which directly impact the success or failure of the company. 
$\mathrm{CG}$ is the backbone for the health of a company. If the corporate culture is sound and of a high standard Nepal enjoy numerous opportunities and can invite global cooperation in terms of investment in large projects. According to the World Bank (2005), in their report on the observance of standards and codes (ROSC) for emerging market countries such as Nepal, improving corporate governance can serve a number of important public policy objectives which includes reducing emerging market vulnerability to financial crises, reinforces property rights, reduces transaction costs and the cost of capital, and leads to capital market development. The legal environment will pave the way but it will not be enough for the organizations to adopt good governance and to attract global investors unless our corporate culture matches global standards. It will be upon our Chambers also to play the catalytic role through awareness programs. The government should encourage by providing incentives for good corporate practices. At least, the public sector boards can take the lead and show more transparency in disclosures of their performances and decision making process. Stress on merit and to be seen taking decisions on merit will be the first step (Agrawal, 2017).

The above discussed situations firmly demand urgency for assessing the prevailing level of policy compliances and their timely revisits for promoting effective corporate governance in the present Nepalese content. This study was aimed to revisit present policies for CG in Nepal. More specifically, the present study has attempted to --

a. assess policy effectiveness on corporate governance,

b. analyze role of public and private enterprises in promoting corporate governance,

c. determine the factors affecting corporate governance,

d. identify issues, challenges and opportunities in corporate governance in Nepal, and

e. examine the legal and regulatory provisions in relation to corporate governance framework in banking institutions of Nepal.

The corporate governance has become a matter of discussion and is taking a central stage for the last few years. For the developing countries like Nepal, it has been receiving a lot of attention for literature and has become an emerging topic for academician in the policy studies. In addition, improving corporate governance can serve a number of important public policy objectives for such a developing economy. Koirala \& Sigdel (2015) have claimed that good corporate governance reduces emerging market vulnerability to financial crises, reinforces property rights, reduces transaction costs and the cost of capital, and leads to capital market development. These scholars have further suggested that weak corporate governance frameworks, on the other hand, reduce investor confidence, and can discourage outside investment.

Regarding the Nepalese politics today, it has been quite stable. We can say that it is in the transition phase. But if we talk about the policies, it is yet to be stabled. Although many perfect regulations and policies are made, they have not been implemented properly. Also, many of the policies are outdated. They need to be timely updated so that the result would be effective enough. 
Nepal is passing through a transitional phase of institutional and governance reform regarding securities market development and gradual transformation of the external sources of corporate finance from bank to market (Pokhrel, 2007). This scholar has further added that the high concentration of corporate ownership structure and dominance of family business groups in corporate affairs have become major constraints in exercising good corporate governance. Nevertheless, a number of governance reforms are underway and some positive symptoms have been observed in the banks and financial institutions.

In order to ensure a good corporate governance in Nepal, it requires a joint effort of the all the stakeholders who need to be more transparent, responsible and socially accountable. They must actively participate in their corporate affairs to help prevent any fraudulent and insider practices. Also, the regulatory authority that should effectively enforce rules and regulations in order to protect the rights of all stakeholders and create favorable environment to enhance good corporate governance culture. With all these understanding, the study team was mainly guided by the purpose to explore this particular area introducing the policies and practices, enforcement mechanism and its effectiveness, and main factors affecting corporate governance in Nepal.

In context of Nepal, a good governance has been the topic of much recent academic work and policy discussion (Khatiwada, 2002; \& Rawal 2003). Paudel and Hovey (2013), as cited in Sigdel and Koirala (2015) has examined the impact of corporate governance on efficiency of Nepalese commercial banks covering 29 commercial banks out of 31 banks in 2005-2011 time duration including corporate governance variables such as board size, independence and diligence, audit committee size, independence and diligence and ownership structure. They also documented that bigger board and audit committee size and lower frequency of board meeting and lower proportion of institutional ownership lead to better efficiency in the commercial banks.

After analyzing all these facts, some questions can be raised --

a. To what extent is the political condition of Nepal firm on promoting corporate governance? Is policy stability yet to be gained?

b. How are the corporate behavioral practices in Nepal? Is it really transforming?

c. Do policies need to be updated?

Corporate governance is the system of accountability among shareholders, the boards of directors and the management of corporate entity (Lusaka, 2005; as cited in Sigdel \& Koirala, 2015). It is of paramount importance to a company and is almost as important as its primary business plan. When executed effectively, it can prevent corporate scandals, fraud and the civil and criminal liability of the company. It also enhances a company's image in the public eye as well as to the all other stakeholders. It dictates the shared philosophy, practices and culture of an organization and its employees. Research has shown that good corporate governance can serve as a tool for attracting better quality investors as well as influencing stock prices (Korac-Kakabadse, Kakabadse \& Kouzmin, 2001; as cited in Siwad, Miruka \& Ogutu, 2015). A corporation without a system of corporate governance is often regarded as a 
body without a soul or conscience. Corporate governance keeps a company honest and out of trouble. If there is no practice of good corporate governance, then, products might be defective and management might grow complacent and corrupt. Dishonest and unethical dealings can cause shareholders to flee out of fear, distrust and disgust.

This paper would be helpful to recognize the various factors affecting corporate governance. It also would help in determining the different issues, challenges and opportunities regarding corporate governance in Nepal. Besides, it analyzes the role of public as well as private enterprises in promoting the corporate governance. This way, the paper covers the several aspects like government agencies, corporate houses and academia and would benefit to them all for different purposes.

From the perspective of making it reader friendly, the study team has established a set of operational definitions of key words used in this paper.

Bank and Financial Institution Act (BAFIA): BAFIA is an umbrella act of all the banks and financial institutions. It aims to protect and promote the rights and interests of depositors, provide quality and reliable banking and financial intermediary services to the general public through healthy competition among banks and financial institutions (BAFIA, 2006).

Basel Committee: The Basel Committee on Banking Supervision (BCBS) is a committee of banking supervisory authorities that was established by the central bank governors of the group of ten countries in 1974. It is the primary global standard setter for the prudential regulation of banks and provides a forum for regular cooperation on banking supervisory matters. The main objective of this committee is to enhance understanding of key supervisory issues and improve the quality of banking supervision worldwide.

Corporate governance: Corporate governance is the system that ensure organization's obligations to its major stakeholders such as customers, employees, creditors, suppliers and distributors, the community, and owners are met with integrity and in compliance with applicable laws and regulations.

Organization for Economic Corporation and Development (OECD) principles: OECD Principles was developed by the ministers of OECD member countries in order to create legal, institutional and regulatory frameworks for corporate governance in their countries and to provide guidance and suggestions for stock exchanges, investors, cooperation that have a role in the process of developing good corporate governance.

\section{Scope and methodology of work}

The main content of the coverage is based on the present policies prevailing in the corporate sector. However, the study focuses on the types of issues, challenges and factors affecting corporate governance. It explores the practices of administrative transparency and accountability, issues concerning the quality assurance of processes and services, policy and political stability and the role of government.

The study adopted an exploratory research design since the study intendeds to gather qualitative data that describes the present policies, role of different enterprises, various issues, challenges and opportunities occurring within the organization and different possible 
strategies for its resolution. The study considers this design appropriate since it facilitated towards gathering of reliable information describing the true characteristics of the factors affecting corporate governance.

The study mostly considered a survey of different public and private enterprises that has been experiencing various types of issues regarding its policies and regulations. Mainly, the secondary sources of data have been collected. To accomplish our study more effectively the instruments like internet, books and magazines were referred. It helps us to gain more knowledge and links our field survey to our course (academic) of the study. Also, different individuals working for different enterprises were contacted in order to make our findings stronger.

This study has not been specified for the particular sector like banking and service industry. Due to the limitation of time frame, the research team is more inclined to the secondary sources of data. Similarly, respondents were limited to Kathmandu Valley which limits the generalizability of the findings. However, the researchers have attempted to maintain the objectivity of the study with tested methods and robustness checks.

\section{Concept of corporate governance}

The studies have suggested that corporate governance is an overview of policies, rules and regulations established to govern the corporation and the people in-charge of the incorporated firm. It defines the relationship between shareholders, board of directors and the concerned stakeholders that determines rules and regulations of the organization (Kulkani \& Maniam, 2014; \& Wheelen \& Hunger, 2006; as cited in Pradhan, 2015).

Corporate governance is the mechanism by which interested parties (the board, management, shareholders and stakeholders) in a corporation interact with each other and promote their interests. Corporate governance is a dynamic phenomenon, in two important ways: First, the interaction among the parties is dynamic. Second, the rights and responsibilities of each of the parties have a time component. For example, members of the board are responsible for: review of documents regarding the company's previous financial period/s; analysis of the company's present financial status; and brainstorming with management about the company's strategy for the future.

According to Cadbury Commission (1992), corporate governance is the system by which companies are directed and controlled. Boards of directors are accountable for the governance of their companies. The key role of shareholders in governance is to appoint the directors and the auditors and also satisfy themselves that an appropriate governance structure is in place. The board's actions should be subject to laws, regulations and the shareholders during the general meeting.

Governance is to steer or to govern a group of people, society, a nation or a state. Definition of governance was traditionally associated with government which was used interchangeably. This definition was later changed in the 1980s, which broadened the meaning of governance by incorporating the role and interconnection of three different actors: Government (state actors and institutions), Civil Society (civil alliances and non-governmental organizations) and Private Sector (households and companies). In this context, the goodness 
of governance will not just depend on triumph or disappointment of one actor but a collective success or failure of all three actors. These actors of governance are correlated. If one of the actors is ineffective, corruption becomes inevitable (Bhandari, 2017).

Perceptions of the elements that constitute good corporate governance vary from country to country since the business environment is not uniform in all countries. Here are some guidelines that can help shape the corporate governance.

According to the Cadbury Committee (1992; as cited in Mulili, 2011), good corporate governance must encompass four key aspects, namely --

a. Establishing a board of directors that has clear responsibilities and whose role of directing or governing is different from that of the firm's managers.

b. Establishing checks and balances in governance structures with no one person having unfettered power.

c. Having a well-balanced board team composed of executive and non-executive directors.

d. Ensuring transparency of a board in directing and controlling an organization.

Another set of five good corporate governance principles is offered by the Organization for Economic Co-operation and Development ([OECD], 1999). The five principles are:

a. Protection of shareholders' rights;

b. Equitable treatment of all shareholders, including effective redress;

c. Recognition of the rights of stakeholders;

d. Timely and accurate disclosure of all matters that are regarded by a firm as being material. These may include financial, performance, ownership and governance matters;

e. Effective monitoring of management and accountability of a board.

According to the research conducted by Sigdel \& Koirala (2015), there are three major factors that have positive impact on perceiving a good governance. They explained as follows:

Transparency: Transparency in any business has been a matter of primary concern for promoting corporate governance. The regular disclosure of periodic financial performance report by management, prompt public announcement of pertinent information by the company's board, the clarity and completeness of publicly relayed information and easy access of senior management to analyst are the factors that helps to promote transparency in banking system.

Accountability: The term accountability simply refers to the answerability of the financial institution to their stakeholders. The basic attention of accountability is concern with the independence and segregation of board of directors and executive committee, commencement of regular and periodic board meetings, the impartial appointment of external auditors and objective and proper review of external auditor's work.

Discipline: Discipline takes into account the focus of firms on their core business. It can be represented by existence or non-existence of explicitly expressed mission statement with focus on corporate governance, the clear focus and stand of top management on the core business of the firm, the internal mechanism to address disciplinary action and its explicit report and provision of the company to include separate section for assessment of company's performance in implementing corporate governance principles in its annual report. 
Corporate governance can be analyzed through seven characters including corporate discipline, transparency, independence, accountability, responsibility, fairness and social responsibility (King Report, 2002).

Figure 1: Factors affecting corporate governance

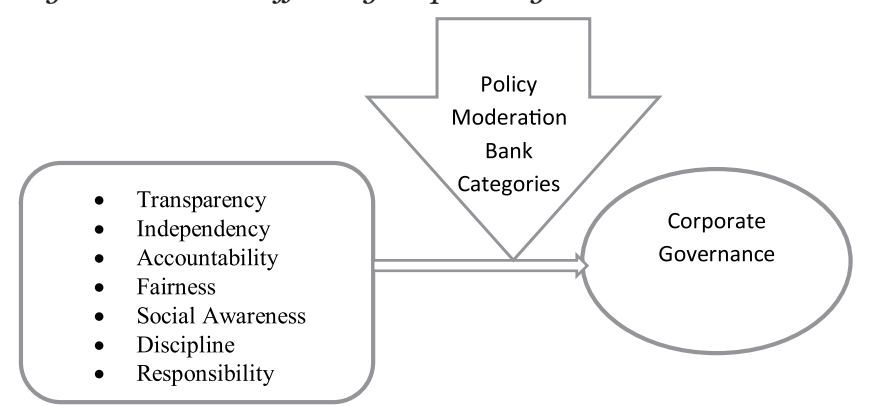

Source: Sigdel \& Koirala (2015). Corporate governance in Nepalese financial sector.

Figure 1 shows the theoretical diagram that depicts the different factors responsible for corporate governance. This diagram indicates corporate governance as a dependent variable and independent factors are transparency, independency, accountability, fairness, social awareness, discipline and responsibility. Bank categories - A, B, and C as per Bank and Financial Institutions Act (BAFIA), 2006 is considered as moderating variables, so as to analyze the effect of policy moderation in overall corporate governance of those banks and financial institutions.

\section{OECD principles of corporate governance}

According to OECD (1999), corporate governance as a set of relationships between a company's management, board, shareholders and other stakeholders. It also provides the structure through which objectives of the company are set, and the means of attaining those objectives and monitoring performance. The corporate governance frameworks are derived from OECD's principles of corporate governance. OECD's principles are generally taken as basis to frame the governance system all over the world, which are clearly summarized below:

a. Corporate governance framework complies with all the laws, rules and regulatory requirements.

b. It helps to recognizes rights, protects and facilitates the exercise of shareholders' rights.

c. It recognizes the equitable treatment of all the shareholders including minority and foreign shareholders.

d. Corporate governance framework should establish a performance enhancement system for active participation of stakeholders.

e. CG framework should ensure the availability of relevant information.

f. It ensures transparency, accountability and professionalism in the management system.

g. CG framework should ensure the respect for norms of business ethics and responsibilities of board. 


\section{Basel committee corporate governance framework}

Basel Committee on Banking Supervision has published a guidance paper in 1999 to assist banking supervisors in promoting and adoption of sound corporate governance practices (Adhikari, 2014). The guidance drew from OECD principles of corporate governance to assist member countries to improve corporate governance in their jurisdictions. Basel Committee's corporate governance framework provides guidance to financial institutions and financial market regulators. The Basel Committee's document, "principles for enhancing corporate governance" set out best practice for banking organizations. Implementation of provisions of Basel II in banking sector forms important part of good corporate governance. The key areas of the principles from the banking and financial industry perspective are highlighted below:

a. Set corporate strategies and values to be communicated in the Banking industry.

b. Define the responsibility and accountability of the board.

c. Ensure the Board members are qualified for their positions, have a clear understanding of their role in corporate governance and be able to exercise sound judgment about the affairs of the bank and are not undue influence from management or outside concerns.

d. The Board and senior management should effectively utilize the work conducted by the internal audit function, external auditors, and internal control functions.

e. The board should ensure that compensation policies and practices are consistent with the bank's corporate culture, long-term objectives, strategy and control environment.

f. The board and senior management should understand the bank's operational structure, including where the bank operates in jurisdictions, or through structures, that impede transparency know-your structure.

\section{Practices of corporate governance}

The broad view of environmental governance is an ensemble of state policies, formal and informal institutions, and practices related to the control and management of the environment for a variety of economic, cultural, ecological, and social values. It involves defining and enacting rules related to the use, control, and management of environmental resources. Such rules emerge either inside the formal system of the state (such as regulatory arrangements) or under traditional and indigenous arrangements of resource control. Policy-making processes and stakeholder engagement is consider as an essential components of environmental governance.

Figure 2 shows the environmental governance at the national and sub-national levels by presenting a broad view of the status of policy and institutions governing natural resources and analyses policy implementation. It focuses on how policies, regulations, and institutions are changing over time and highlight important gaps related to the lack of coherence, deficits in implementation, and tendency to ignore evidence in policy-making processes. Furthermore, it also assess local level environmental governance, focusing on community-level institutions and local government. As it demonstrate, decentralized and community-based 
Figure 2: Framework of multidimensional governance

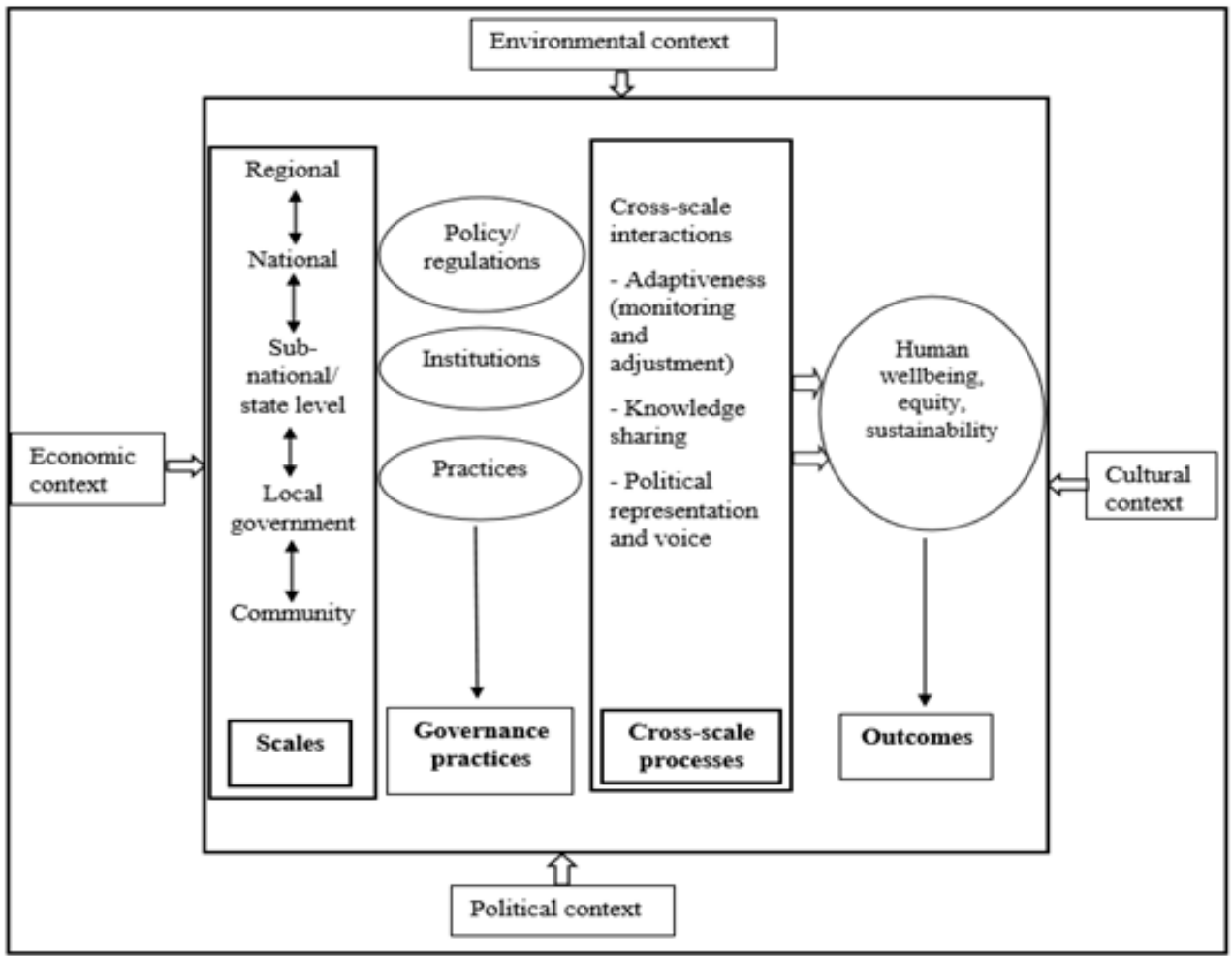

Source: Ojha et al. (2019). Governance: Key for environmental sustainability.

approaches to environmental management have emerged as a global agenda for advancing sustainable development, and considering this shift in global policy debate.

Similarly, regarding corporate governance practices in Nepalese Banks, the corporate governance principles from the banking perspectives it is clear that corporate governance ensures transparency, accountability and professionalism in the financial system that enhances the credibility and acceptability to the shareholders, employees, present and potential investors, customers, lenders, governments and general public. Since Banks deal in public money and public confidence is of outmost importance (Gorkhali, 2010). Corporate governance should be strengthen through setting the clear strategies, well-defined organizational structure to implement the strategic, transparent reporting system in an ethical manner and controlled environment (Kharouf, 2000).

In Nepalese context, most of the corporate governance practices are expected to evolve under the regulatory requirements of the Nepal Rastra Bank (NRB) rather than other laws and rules. Therefore, in this section, history and general environment of banking institutions in Nepal and applications of corporate governance with reference to OECD Principles of Corporate Governance and Basel Committee on Banking Supervision framework are discussed. In developing countries such as Nepal, a good governance of Banks is crucial for the survival of its economy. 


\section{Legal and regulatory environment in the Nepalese banks}

Nepalese banks are regulated by the Bank and Financial Institutions Act (BAFIA) 2006, Company Act 2006 and regulated by Nepal Rastra Bank. After the operations of the joint venture commercial banks in Nepal since 1984, they brought modern banking system and exercise to establish the good governance practices in Nepalese financial system. In considering the general banking environment in Nepal, it is important to emphasize the banking laws, commercial laws and regulatory frameworks. Adhikari (2013) has stated that financial reporting standards issued by the professional bodies will affect the local practices and the development of adequate laws and regulations. Accordingly, application of accounting standards and auditing practices impact the environment of the company.

Another contributing factor is the level of exposure of the banking institutions to international regulations. The banks with a foreign ownership are more likely to have an advanced level of corporate governance than those with limited international exposure. Another important common dimension that is relevant to corporate governance is the strong family control of ownership, boards of directors and management (Mundul, 2005).

Moreover, Nepalese financial institutions in general are limited in their traditional banking activities. This limitation may also imply still weak corporate governance in general. In spite of these issues, most Nepalese banks are small in size compared to the major financial players in the international markets. There are thirty-one commercial banks operating banking business in Nepal as on July 2013 (NRB, 2013). Commercial banks dominate the overall financial sector with limited role of non-bank financial institutions and the capital market. The banking sector alone accounts for a substantial share of assets of the financial system.

Nepalese banks are trying to continue to innovate new product and global networking of the banking environment with implementation of strong corporate governance framework. Nepal Rastra Bank, as the regulator, has the responsibility to supervise the nature of corporate governance practices in the banking sector. Government of Nepal and Nepal Rastra Bank has continued the financial sector reform program and emphasizes the maintenance of good governance practices in financial sector that create the environment to ensure the flow of foreign investment. The major recommendations of the OECD and Basel Committee on Banking Supervision are being adopted by the Nepalese banks in order to safeguard the stability of the economy and financial system.

\section{Present policy status on corporate governance in Nepal}

Capital markets: The capital market of Nepal is relatively small compared to other nations. The development of a capital market has been delayed due to a lack of proper rules and regulations for investors' protection and good governance (The World Bank, 2005; as cited in Acharya, 2018). The NEPSE operates as the country's sole stock exchange under the Securities Act, 2007. The main function of NEPSE is to provide a platform for trading securities. The Securities Board of Nepal (SEBON) acts as the apex regulator for the securities markets in Nepal under the Securities Act, 2007 (The World Bank, 2015).The banking sector plays an important role for the development of capital markets, however in Nepal, compared to other 
developing nations, the banking sectors seems to be less efficient due to an increase in NPL, shortfall in capital, ineffective supervision, and slow recovery rate .Nepal had embraced a dematerialized share trading system by replacing the traditional paper based system only during January 2015. The dematerialized process has led to an increase in the number of retail investors and volume of trading (Acharya, 2018). Good CG encourages investor confidence and outside investment.

Banking, finance and others corporate sector: The World Bank and IMF initiated their support since 1980 for improving Nepali banking, financial institutions and others corporate sector reform which is still going on. Banking and financial institution ordinance was enforced in 2004. Main objective of law is to deregulate the banks and financial institutions. Nepal also introduce few corporate law in 2005 with the help of Asian development bank (ADB) corporate sector project. Company ordinance, bankruptcy ordinance, secured Transaction Ordinance 2005 are few examples. Main objective behind such laws is to promote corporate governance in Nepal. ADB's assistance in Nepal began in 1968 it has also playing important role to liberalize Nepal's economy. ADB's assistance is primarily on sector life agriculture and rural development, education water supply, sanitation, infrastructure and public and private sector governance.

Nepal Rastra Bank ([NRB], 2002) maintains the independence and autonomous rights to act as the central bank, is free from government intervention to formulate monetary and foreign exchange policies to maintain price stability, balance of payment, develop a secure, healthy and efficient payment system, appropriately regulate, inspect and supervise banks and financial systems and enhance public credibility towards banks and financial systems. NRB (2002), in its directives, has maintained several requirements to prevent political intervention and maintain professionalism in NRB by specifically mentioning the criteria for the formation of boards of directors including appointment of governor and deputy governor, their qualifications, code of conduct, terms of directors and remuneration and other benefits of directors. Further, it mentions the constitution, functions and duties of the inquiry committee, meetings of the board, their functions, duties and power and professional code of conduct and official responsibilities (NRB, 2002).

The central bank of Nepal, NRB has been playing a big part in supporting corporate governance in the most prominent public sector in Nepal i.e., banking sector. NRB redundantly issues several corporate governance guidelines for the banking sector. NRB issued policies which includes guidelines for board of directors, managers and shareholders, role of internal and external audit, etc. to protect the interest of the shareholders, boost investors' confidence and capacity building or in other words, to foster good governance (Ministry of Finance [MOF], 2006). Some of the notable guidelines that encourages good governance are enlisted below:

Board of Directors: The board of directors is a collective body that should act in the best interest of shareholders. The board requires the combination of executive and non-executive directors to pursue the shareholders' interest. The non-executive directors on the board will not be able to exercise their duties effectively, unless they are independence from management and ensure they provides unbiased business judgment. Independent directors are the 
person entrusted by shareholders to represent them and will help to reduce agency problems (Fuzi, Halim \& Julizaerma, 2016).

As per the Bank and Financial Institutions Act, 2006 all banks must have a board of directors of between five to nine members including one professional director from the list provided by the NRB. The directors are appointed at general or annual general meetings of the Banks and Financial Institutions (BFI) and not more than one member from same family are eligible. In case of Independent Directors person of his/her family who subscribed more than $1 \%$ shares of concern BFI's are not eligible for different Directors of BFI's. Same person does not eligible for different BFI's Board of Directors (MOF, 2016). BAFIA 2017 has mentioned some specific responsibilities to the Board of Directors, which are pinpointed below:

a. No board directors are entitled to derive any personal benefits from the bank or financial institutions while performing the role.

b. If any director is found to have derived personal benefit, then the financial institution has the right to recover that amount from the director.

c. If any directors take any decision beyond his/ her responsibility and cause harm to the bank, the bank or financial institution will not be responsible for any action taken by that director.

d. The board should prescribe the remuneration and benefits of the chief executive.

Management: Since BAFIA 2006, there has been a slight change in the appointment criteria for the CEOs of banks and financial institutions. A bank CEO must have completed a Master's degree in management, banking, financial, 65 monetary and economics, commerce, auditing, statistics, or law. Or, alternatively, they may have a Bachelor degree and at least 10 years working as an officer in these areas to be eligible to become a bank CEO. Furthermore, just as it is for the board of directors, for any individual to be appointed CEO, he/she must be a normal person, and should not be have been declared bankrupt or have any fraud or dishonest offence. The chief executive officer of a bank can have a two-year tenure and is responsible for the preparation of the annual budget and action plan which he/she presents to the board for approval before implementation (NRB, 2006).

Audit committee: The Companies Act, 2006 requires all the listed companies with the paid up capital of NPR 30 million, which is fully or partly owned by the government, to have an audit committee under the chairmanship of a non-executive director who is not involved in the day to day operations of the company. Further, this Act prohibits any close 65 relatives of the CEO to be the members of the audit committee. The Companies Act, 2006 has highlighted the responsibilities of the audit committee as:

a. To review the accounts and financial statements of the company

b. To review internal financial control and risk management systems

c. To supervise and review internal auditing activity of the company

d. To recommend the names of potential auditors for the appointment of the auditor of the company and fix their remuneration and terms and conditions

e. To review the remarks contained in the external audit report and take 67 necessary actions if required. 
f. To provide board of directors about the accurate information about the company.

g. To prepare accounts related policy of the company and enforce it.

Audit committee has a vital role in fostering good governance in the business scenario of Nepal. Despite the body playing its role, many cases have been reported that addressed the issues of frauds and miscommunication. For an instance, Gurkha Development Bank Executive Chairman DB Bamjan is facing charges over alleged irregularities while lending Rs. 130 million to one Pancha Lal Maharjan. The central bank has found that Maharjan did not actually receive the amount. The central bank also found that the bank directors were involved in insider trading, as the bank was in a process to purchase land of a promoter against the banking norms. Such cases would not be possible if there was a strong audit committee. Such bad practices can never lead the business towards prosperity.

Public utilities and privatization: Privatization is one of the major components in the process of economic liberation. However, the impact of privatization is always contended. The experience in different countries has shown that privatization of public utility service is very sensitive. In Nepal the government has decided to open banking, education, health, telecommunication services for private sector. After Nepal's accession to WTO, the schedule of commitment was determined for other areas of services that Nepal has to open within stipulated time frame. Many developing countries have embarked on various forms of market-oriented reforms to modernize their economies, and the privatization of state-owned enterprises has often been a centerpiece of such reforms.

Privatization, however, presents special challenges for both the public sector governance and corporate governance in developing countries like Nepal. In some transition economies, weak corporate governance has facilitated the corrupt officials in looting the already impoverished states during the process of privatization (Black, Kraakman \& Tarassova, 2000; as cited in $\mathrm{Wu}, 2005)$.

Trade and investment: Policies and institutional framework necessary for making industrial sector more competitive were devised in early 1990s. Basically, the laws and policies that govern industrial activities and related service are:

a. Industrial Policy 1992

b. Industrial enterprises act 1992

c. Foreign direct investment policy $1992^{`}$

d. Foreign direct investment and technology transfer act 1992

e. Privatization act 1993

f. Electricity act 1992 and water resources act 1992

These initiatives aim at both deregulating and streamlining investment and procedure. Both domestic and foreign government is encouraged. The liberalized trade regime refers to elimination of all quantitative restriction and import license. In fact, Nepal has already ensured the most favored nations and national treatment. 


\section{Issues and challenges facing CG in Nepal}

Good governance in Nepal is needed in every field. It is vital for making proper use of the human, material, and financial resources. It is required to meet the needs of people by mobilizing internal resources, controlling corruptions and many more. By maintaining good governance in Nepal, we can fulfill public needs, distribute national income proportionately, provide speedy and credible services, control bribery, irregularities and promote public confidence in the institutions, it is important to check corruption and impurity to promote the interests of underprivileged.

It is difficult to achieve good governance in totality in a country like Nepal, yet it is not impossible. There are many seen and unseen, some deeply rooted challenges to Nepal. Challenges of Good Governance in Nepal are mainly as follows:

Illiterate and weak civil society: Civil society consists of a range of local groups, specialized organizations whose function is to mediate between the individual and the State. Our civil society seems quite weak as it has less participation and involvement that is permitting the high level of corruption and misuse of power.

Low accountability, responsiveness and transparency: Accountability and responsibility are the most essential things for good governance in Nepal. Good governance requires accountability on the part of every institution: government or private, and also civil society towards the people going to be affected by its decisions or actions. They should be equally responsible towards their duties. Here, lack of accountability and responsiveness is one of the main obstacles of good governance in Nepal. Also, to maintain the transparency is one of the major problems of good governance in Nepal. Good governance can be promoted only where decisions are made and implemented according to rules and regulations in a transparent way and public information is freely and easily made available.

Deeply rooted corruption: Nepal, now-a-days is going through many corruption issues which has severe effects not only on business but in an economy of nation as a whole. Almost all the organizations are allowing the corruption which directly shows the practice of bad governance in Nepalese organization. Not a single day can be passed without a news entitled with the headline of corruption. The government should put its eye upon it as soon as possible.

Weak law enforcement and impunity: Although the policies and laws are amazing, they are not executed properly in almost every sector. It shows that government is not monitoring properly. And no one miss the chance to disobey the law. It means that both the government and the civil society should be responsible enough in this case. Thus, the company should operate within the legal frameworks that are enforced by regulatory bodies, for the full protection of stakeholders and government should supervise parallel.

Equity and inclusiveness: Equity and inclusiveness is most essential things for good governance in Nepal. It should be ensured that nobody feels excluded from the main stream of the society. As far as possible, every section of the society should be represented proportionately. Here in Nepal, lack of equity and inclusiveness is one of the main obstacles of good governance in Nepal. 
Unstable policies: After such a long period of political instability, Nepal has achieved quite stable government. However, there is still absence of policy stability. They are not upto-date and properly reformed. A policy of corporate governance needs a clear enforcement mechanism, applied consistently, as a check and balance against the actions of executive staff.

Low innovation in governance system and traditional mindset: Nepalese corporate sector is more inclined to the imitation rather than innovation. Mostly, the government organizations are performing in a traditional way. Every corporate body needs to take the risk of innovation, i.e. innovation in products, in services and it plays a pivotal role in corporate governance.

To fight against the above challenges and to bring about good governance in Nepal, governmental, private sector and every individual should work together. There have to mass awareness and educational programs launched. A structural reform has to be affected; our official and legal working procedures should be appropriately improved. Civil society and private sector should play more active role. Judiciary and law enforcing agencies should be appropriately empowered, trained and equipped. All of Nepali mindset needs to be changed as per time. We all Nepalese should transform the administration from process oriented into action and service oriented.

\section{Role of public and private enterprises in promoting good governance}

The effectiveness in the practices of corporate governance all depend upon the performance of both public and private enterprises. The framework of all those enterprises should have such attributes that contribute to effective governance and tools for addressing governance risk. A framework helps define the role of the board and management, delineates duties and helps prevent duplicated efforts and the overlooking of critical issues (WSJ, 2013).It should provide the strong construct for evaluating how management's responsibilities fit with the board's oversight responsibilities.

Effective and efficient management of public sector organizations is an issue of concern in many countries. Melese et al. (2004; as cited in Mulili, 2010) have argued that public sector organizations are increasingly being held more accountable for their performance and are therefore expected to operate efficiently and effectively. This means that public sector organizations have to search for ways to improve on their activities. Similarly, activity based management practices can increase transparency and efficiency when conducting government activities thereby assisting public sector organizations to achieve their objectives (Baird, 2007; Melese et al., 2004; as cited in Mulili, 2010). Recently, banking industry holds the major portion of public sector enterprises. Nepal Bankers Association (NBA) claims that the banking sector has the highest standards of corporate governance. It is true in comparison with many other institutions in the country, which are completely non-transparent. This is one of the reasons why the financial sector has shown encouraging growth in the country. But there is always considerable scope for improvement.

The Companies Act, 2006 has made the following mandatory provisions for the public enterprises:

a. It requires at least seven shareholders and promoters.

b. Annual General Meeting (AGM) should be held every year within six months after 
the expiry of fiscal year. Extra-ordinary General Meeting (EGM) can be called by the Board of Directors (BODs), if it deems necessary.

c. Each company shall have Board of Directors consisting of minimum of three and maximum of eleven members. Meeting of the BOD s should be held at least six times a year.

d. While forming the BODs, at least one Independent Director should be nominated in the case of the number of directors not exceeding seven, and at least two Independent Directors should be nominated in the case of the number of directors exceeding seven. The Independent Directors should be appointed amongst the persons who have knowledge and work experience as prescribed in the Articles of Association of the company.

e. No director of a company shall do anything to derive personal benefits from the company or in the course of conducting business of the company. If founded doing so, the company shall recover the amount involved in the matter from such director as if such amount were a loan.

Nepal report on the observance of standards and codes accounting and auditing (ROSC) observations: The Nepal ROSC A \& A team reviewed a sample of 20 financial statements from commercial banks; insurance companies; an airline; a hotel; and hydropower, manufacturing, and telecommunication companies. The team found significant differences in the accounting standards and policies adopted with regard to International Financial Reporting Standard/ International Accounting Standard. The team found that noncompliance is considerable which definitely raises the question of integrity regarding corporate governance regarding the statements that provide information about the financial position, performance and changes in financial position of an enterprise (The World Bank, 2015).

The ROSC team also observed that the audit firms are conducting audits of historical financial statements in compliance with the auditing standards. However, some deficiencies was felt in areas of risk assessment, audit sampling and planning, management representations, supervision and documentation of audits, and quality control for audit work. These deficiencies need to be aligned and enforced in line with International Standard of Auditing.

In addition, most general purpose financial statements here are not prepared in accordance with the applicable accounting standards as per ROSC observation. As many interviews and discussions with stakeholders and regulators revealed that there are serious concerns about the quality of financial reporting. Entities have given low importance to financial reporting. Adding to this, the low-level skills of accounting professionals, lack of capacity of the regulators, and the lack of sanctions resulting from poor oversight, etc. are the major issues observed by ROSC.

Nepal's private sector is dominated by small- and medium-scale enterprises, which comprised more than $90 \%$ of the total registered businesses. The private sector is recognized as one of the important pillars of the economy with its vital role in achieving higher growth. The government is now promoting private sector participation in infrastructure development 
of hydropower plants, irrigation, roads, and airports and has begun creating an enabling environment for private investment. However, the private sector of Nepal is not being able to compete in the global market due to the various reasons such as small size, large degree of informality, and lack of innovation. This finally results in limited economies of scale and low profitability. Dominant large firms are generally family-run and have survived mostly due to a lack of competition. This is changing, however, with market liberalization allowing foreign investment and increasing internal capacity due to the influence of and exposure to such investments (ADB, 2013).

Even the majority of the registered businesses are covered by small and medium-size entities (SMEs), there is no clear definition for SMEs in law, and they do not have separate standards to be followed for preparing financial statements. Because of that, SMEs in Nepal are facing challenges regarding financial reporting and transparency. SMEs, generally, are small sized companies with no public accountability. They exist in all sectors except for financial and insurance (The World Bank, 2015). The remaining large private enterprises are mostly family-led, where the family owns a majority interest in the company or a controlling minority interest. Many of the largest firms in this segment are held in holding companies or are otherwise part of a family group of firms, alongside other firms that may be wholly owned, joint ventures with foreign firms, or other family-led corporations.

The Companies Act, 2006 has made the following mandatory provisions for private enterprises:

a. It requires minimum one shareholder or promoter.

b. The company shall have Board of Directors consisting of maximum of eleven members.

c. Each private company shall submit a copy of the annual financial statement certified by the auditor to the office of the Company Registrar within six months of the completion of fiscal year.

The basic belief of effective corporate governance hinges on honesty, trust, integrity, openness, performance, orientation, responsibility, accountability, mutual respect and commitment to the organization. Organizations need to develop a model of governance that aligns the value of corporate governance.

\section{Outcomes of effective corporate governance}

The essence of good corporate governance is ensuring trustworthy relations between the corporation and its stakeholders, government and civil society. Therefore, good governance involves a lot more than compliance. The success of every sector of economy and nation depends upon the good governance which is a culture and a climate of consistency, responsibility, accountability, fairness, transparency and effectiveness that is deployed throughout the organization (Arguden, 2010). Some of the major outcomes of corporate governance include:

a. Giving stakeholders confidence that the business is being run to important legal standards so that it never violates applicable laws or regulations, including the unwritten rules of good, ethical behavior. 
b. Providing transparency in the company's decision-making processes both in good and bad times.

c. Regulating efficient cooperation between a supervisory board of directors and the management of a company.

d. Ensuring the company exercises prudence in strategy-setting and decision-making so that the best interests of all stakeholders are taken into account.

e. Providing a framework for action if there's a violation of the company's code of conduct.

f. Ensuring the company is geared toward long-term value creation, not short-term gains.

When the company's management works according to a well-defined corporate governance structure, the well-being of everyone involved in the company should automatically be taken care of. Beside this, there are many more outcomes of good governance practice. They are:

Improved reputation: Edmunds (2018) has stated that a corporate governance program can boost the company's reputation. If the corporate governance policies and detail how they work are publicized, more stakeholders will be willing to work with the organization. The practice of sharing internal information with key stakeholders is known as transparency, which allows people to feel more confident you have little or nothing to hide.

Fewer fines, penalties, and lawsuits: Corporate governance includes instituting policies that require the company to take specific steps to stay compliant with local, state and federal rules, regulations and laws (Edmunds, 2018). It might require that the accounting department undergo an external audit by an independent auditor every quarter or year.

Decreased conflicts and fraud: Corporate governance limits the potential for bad behavior of employees by instituting rules to reduce potential fraud and conflict of interest.

Sound environment for conducting business: Practice of good governance encourages people to invest and conduct the business. The risk for the investors will be low if there is fairness and transparency in business. Thus, they do not hesitate to invest. Also, employees feel good and safe to work in such environment. Therefore, overall performance of the business goes smoothly. This way, all individuals, businesses and the nation can be benefited from the practice of good governance.

\section{Major findings}

a. Most of the Nepalese banks are trying to continue the innovation of new products and global networking of the banking environment with the implementation of strong corporate governance frameworks.

b. Nepal Rastra Bank (NRB) has been playing a big role in supporting corporate governance in the most prominent public sector in Nepal. NRB also issued some policies which includes guidelines for board of directors, managers and shareholders, role of internal and external audit etc. in order to protect their interest and to foster good governance. 
c. There is no clear definition of rules, regulations and laws for SMEs and also they do not have separate standards to be followed for preparing financial statements which tends to have low transparency and challenges regarding financial statements.

\section{Conclusions}

Good governance is usually expressed as a collective happening of rule of law, transparency, accountability, fairness, responsibility, participation, equity and inclusiveness. It plays an important role in achieving social and economic development. Policy reforms have been a key factor in improving capacities of OECD countries to address issues such as financial crises, competitiveness, boosting the confidence of government, and so on. The quality of governance is recognized as fundamental to ensure the quality of life of citizens. The sustainability and the strength of democracy are all reflected on the level of practice of good governance.

Although several legal compliances are set by the Company Act and other similar policy premises, most of the cases, respective policy guidelines and operating standards are yet to be fully implemented. Nepalese enterprises are facing the issues of corruption, unsupportive civil society, weaker enforcement of law, unstable policies and low level of industrial innovation. It is also seen that the public enterprises are more inclined to good governance in comparison to private enterprises.

For emerging market countries, improving corporate governance can serve a number of important public policy objectives such as reducing market vulnerability to financial crises, reduces transaction costs and the cost of capital, and leads to capital market development. Weak corporate governance frameworks reduce investor confidence, and can discourage outside investment. Therefore, over the past several years, the importance of corporate governance has been highlighted with an increasing body of academic research (The World Bank, 2005) in this particular domain.

\section{Recommendations for policy implications}

The system of governance not only affects the firm's performance but also has its impact upon the development of the state. Good governance depends on institution-wide ability to exercise power and to make effective decisions over time, across all dimensions of socio-economic, political-legal, technological and international environmental premises. This is again linked with the government's capacity for knowledge development and management, mediation, resourcing, implementation and maintenance of key relationships. We, as a study team in this discourse, have produced a few important recommendations for policy implications in this respect:

a. There should be review provision in the Company Act, 2006 by mentioning a size threshold for companies required to have their financial statements audited. The law currently requires all companies, irrespective of their size, to be audited in the same degree. The threshold should be established as such that the companies above a certain size should be audited, and those below the threshold should present financial statements in a compilation format. 
b. In the current scenario, key corporate governance institutions such as Securities Board of Nepal (SEBON) and Office of Company Registrar (OCR), there is lack resources and authority. In conjunction with the new legislation, priority must be given to strengthen these institutions charged with enforcing governance requirements. Reforms should be made for OCR that include changes on technical upgrades to modernize its systems for filling and documentation. The OCR should be able and willing to demand that delinquent companies hold the AGM and make proper filling in time.

c. For SEBON, additional resources and authority should be delegated to strengthen itself as a serious capital markets regulator. It should also be able to impose fines and reverse abusive or incorrect corporate actions.

d. The government should focus on enhancing corporate transparency by mandating all listed companies to follow national standard for accounting and auditing; with assurance that high standards are introduced and implemented. In this, Institute of Charter Accountant of Nepal (ICAN) has to play a significant role by ensuring that the standards it issues adhere closely with the International Financing Reporting Standard (IFRS) and International Audit Standard (IAS). It will be very critical to maintain high level of professionalism from its members. Thus, training on member capacity building should be instituted.

e. Nepalese corporate environment has suffering from an adverse tradition of nepotisms and favoritisms. It creates a discouraging situation for competitively performing employees just because they are less favored. It may also create hostile working environment where the employees no longer feel to perform the job as their ethical and responsible duties. They may take it for granted which in turns results in low productivity. Mostly, the practices of such nepotisms and favoritisms are seen in private enterprises, producing a culture of discrimination. The provision for 'right to sue' should be made if in case, it is proven.

f. Promoting and embracing the adaptation of a corporate governance culture in the organization should be given the utmost priority. A robust corporate culture should be established and maintained, in both small and large scale enterprises. For that companies need to invest in good governance by leveraging the power of information technology (IT) and government should support it by associating with international associations in order to raise awareness of good corporate governance practices in national public and private sectors.

\section{References}

Acharya, S. (2018). Improving corporate governance in Nepalese financial institutions to promote growth and performance. Unpublished masters' thesis report, University of Waikato. Available at: https:// researchcommons.waikato.ac.nz/handle/10289/11720. Retrieved on: April 15, 2019.

Adhikari, P. (2013). Nepal on the path of IFRS implementation. Journal of the Institute of Chartered Accountants of Nepal, July-September 2013 Issue. Available at: https://abhinavjournal.com/journal/ 
index.php/ISSN-2320-0073/article/view/416. Retrieved at: May 15, 2019.

Adhikari, P. (2014). Corporate governance practices in commercial banks in Nepal. Abhinav International Monthly Refereed Journal of Research in Management \& Technology, 3(9), pp. 55-56. Available at: https://abhinavjournal.com/journal/index.php/ISSN-2320-0073/article/viewFile/416/ pdf_109. Retrieved on: May 17, 2019.

Aggarwal, P. (2013). Corporate governance and corporate profitability: are they related? A study in Indian context. International Journal of Scientific and Research Publications 3(12), 1-8. Available at: http://www.ijsrp.org/research paper1213/ijsrp-p2499.pdf. Retrieved on: January 21, 2019.

Agrawal, J. P. (2017, April 16). Corporate governance. New Business Age. Available at: http://www.newbusinessage.com/MagazineArticles/view/1743. Retrieved on: February 11, 2019.

Arguden, Y. (2010, April 16). Measuring the effectiveness of corporate governance. The Business School of the World. Retrieved on: February 7, 2019. Available at: https://knowledge.insead.edu/leadership-organisations/measuring-the-effectiveness-of-corporate-governance-1149. Retrieved on: January 25, 2019.

Asian Development Bank [ADB] (2013). Private sector assessment (summary). Country Partnership Strategy, Nepal. Available at: https://www.adb.org/sites/default/files/linked-documents/cpsnep-2013-2017-psa-summary.pdf. Retrieved on: February 11, 2019.

ASX Corporate Governance Council, (2003). Principles of good corporate governance and best practice recommendations. Sydney: Australian Stock Exchange Ltd. Available at: https://www.asx.com.au/ documents/asx-compliance/principles-and-recommendations-march-2003.pdf. Retrieved on May 9, 2019.

Basel Committee. (2006). Enhancing corporate governance for banking organizations. Section II: Bank for International Settlements, $\mathrm{CH}$-4002. Switzerland: Basel. Available at: http://www.bis.org/publ/ bcbs122.pdf. Retrieved on: May 11, 2019.

Cadbury Commission. (1992). Report of the committee on the financial aspects of corporate governance. London: Gee. Available at: https://www.governance.co.uk/resources/item/255-the-cadbury-report. Retrieved on: May 15, 2019.

Edmunds, S. A. (2018). The advantages of corporate governance. Small Business, Chron. February 7, 2019. Available at: https://smallbusiness.chron.com/advantages-corporate-governance-65692.html. Retrieved on: January 25, 2019.

Fuzi, Halim \& Julizaerma (2016). Board independence and firm performance. Procedia Economics and Finance, 37, 46o-465. Malasiya: Science Direct. Available at: https://www.sciencedirect.com/science/article/pii/S2212567116301526. Retrieved on February 11, 2019.

Gorkhali, A. (2010). Corporate governance from national and international perspective in banks and financial institutions. Journal of the Institute of Chartered Accountants of Nepal, 3(9), pp. 56-64. Available at: http://www.abhinavjournal.com/journal/index.php/ISSN-2320-0073/article/ view/416. Retrieved on: May 10, 2019.

Koirala, S., \& Sigdel, B. R. (2015). Corporate governance in Nepalese financial sector: does policy matter?Research Committee. Lalitpur: Nepal Administrative Staff College. Available at: http://dms. nasc.org.np/author/basanta-raj-sigdel-santosh-koirala. Retrieved on: January 4, 2019.

Ararat, M., \& Ugur, M. (2003). Corporate governance in Turkey: an overview and some policy recommendations. Corporate Governance: The International Journal of Business in Society, 3(1), 58-75. Available at: https://www.researchgate.net/publication/235271462_Corporate_Governance_ 
in_Turkey_An_Overview_and_Some_Policy_Recommendations. Retrieved on: May 16, 2019. Ministry of Finance. (2006). Bank and Financial Institutions Act, 2006. Kathmandu: Government of Nepal. Available at: http://www.nepalmissiongeneva.org/downloads/investment/banks-and-financial-institutions-act.pdf. Retrieved on: February 1, 2019.

Ministry of Industries and Commerce. (2006). Company Act, 2006. Kathmandu: Government of Nepal. Available at: http://www.lawcommission.gov.np/. Retrieved on: February 10, 2019.

Mulili, M. B. (2010). Corporate governance practices in developing countries: the case for Kenya. International Journal of Business Administration, 2(1), pp. 14-27. Available at: http://citeseerx.ist.psu.edu/ viewdoc/download?doi=10.1.1.1023.6635\&rep=rep1type=pdf. Retrieved on: February 10, 2019.

Mundul, S. (2005). Corporate governance: banks and financial institutions perspectives. Corporate Governance Principles and Practices. A seminar paper, 5 July 2005. Kathmandu: Securities Board of Nepal (SEBON).

Nepal Rastra Bank (2002). Nepal Rastra Bank Act, 2002. Available at: https://nrb.org.np/lgd/acts_ordinances/nepal_rastra_bank_act_2002_[english].pdf. Retrieved on: February 8, 2019.

Organization Economic Corporation and Development [OECD] (1999). OECD Principles of Corporate Governance. Available at: http://www.oecd.org/corporate/ca/corporategovernanceprinciples/31557724.pdf. Retrieved on: February 9, 2019.

Ojha, H. R., Ghate, R., Dorji, L., Shrestha, A., Paudel, D., Nightingale, A., \& Kotru, R. (2019). Governance: key for environmental sustainability in the Hindukush Himalaya. The Hindukush Himalaya Assessment, 545-578. Springer, Cham. Available at: http://www.bookmetrix.com/detail/ chapter/808b39ad-ef56-484f-96e1-88614d4728f2\#downloads. Retrieved on: May 10, 2019.

Pradhan, R. S. (2015). Corporate governance and bank performance in Nepal. Available at: http://dx.doi. org/10.2139/ssrn.2793445. Retrieved on: January 20, 2019.

Pokhrel, D. (2007). Corporate governance in Nepal. Socio-Economic Development Panorama, 1(1), 39-53. Available at: https://www.nepjol.info/index.php/sedp/article/view/1182. Retrieved on: January 22, 2019.

Rijal, C. P. (2019). Management development scenario 2018. Background paper, 38, 15-42. Kathmandu: Management Association of Nepal.

Siwadi, P., Miruka, C., \& Ogutu, F. A. (2015). The impact of corporate governance on firm performance in the Zimbabwean manufacturing sector. Corporate Ownership \& Control, 12(4-7), 779-79o. Available at: http://doi.org/10.22495/cocv12i4c7p8. Retrieved on: January 4, 2019.

The World Bank (2015). Corporate governance country assessment. Report on the Observance of Standards and Codes Accounting \&Auditing (ROSC). Available at: http://documents.worldbank.org/ curated/en/223031468323342200/pdf/ACS1434-REVISED-Box394844B-PUBLVC.pdf. Retrieved on: March 10, 2019.

The World Bank (2005). Corporate governance country assessment. Report on the Observance of Standards and Codes Accounting \& Auditing (ROSC). Available at: http://documents.worldbank.org/curated/en/279161468062634544/Nepal-Report-on-the-Observance-of-Standards-and-CodesROSC-corporate-governance-country-assessment. Retrieved on: February 10, 2019.

$\mathrm{Wu}, \mathrm{X}$. (2005). Corporate governance and corruption: a cross-country analysis. Governance: An International Journal of Policy, Administration and Institutions, 18 (2), 151-17o. Available at: https://core. ac.uk/download/pdf/48636153.pdf. Retrieved on: February 11, 2019. 